\title{
Distinct plasmid profiles of Pasteurella haemolytica serotypes and the characterization and amplification in Escherichia coli of ampicillin-resistance plasmids encoding ROB-1 $\beta$-lactamase
}

\author{
A. K. Azad, J. G. Coote* and R. Parton \\ Microbiology Department, University of Glasgow, Glasgow G12 8QQ, UK \\ (Received 23 January 1992; revised 19 February 1992; accepted 25 February 1992)
}

\begin{abstract}
Thirty-five isolates of Pasteurella haemolytica from cattle or sheep were screened for the presence of plasmids and for resistance to a range of antibiotics. Eight strains (four of serotype A1, three of serotype A2 and one untypable) contained plasmid DNA and isolates of the same serotype had similar plasmid profiles, which were different from those of the other serotypes. All but one of the plasmid-bearing strains were isolated from pneumonic animals or from animals in contact with pneumonic cattle or sheep. In A2 and untypable strains, there was no obvious correlation between antibiotic resistance and the presence of a specific plasmid. In contrast, all plasmid-bearing A1 strains exhibited ampicillin resistance $\left(\mathrm{Ap}^{\mathrm{R}}\right)$, which was shown by transfer studies to be plasmid-mediated. Plasmid DNA prepared from $E$. coli transformants was not routinely detected on ethidium-bromide-stained agarose gels, but could be amplified to detectable levels by treatment of cultures with chloramphenicol $(\mathrm{Cm})$ or by modifying the growth conditions. The $A^{R}$ plasmids from $P$. haemolytica were identical by restriction enzyme analysis. Restriction analysis and hybridization data indicated that these plasmids were closely related to the prototype ROB-1 $\beta$-lactamase-encoding plasmid, originally isolated from Haemophilus influenzae. From substrate profiles and isoelectric focusing data, the $\beta$-lactamases encoded by the $P$. haemolytica plasmids were indistinguishable from the ROB-1 $\beta$-lactamase.
\end{abstract}

\section{Introduction}

Pasteurella haemolytica, a Gram-negative bacterium, is an important pathogen of domestic ruminants and causes a substantial economic loss to the cattle and sheep industries (Yates, 1982; Donachie, 1988). The presence of plasmids and their association with antimicrobial resistance phenotypes in this species has been described previously (Zimmerman \& Hirsh, 1980; Boyce \& Morter, 1986; Chang et al., 1987; Haghour et al., 1987; Livrelli et al., 1988; Schwarz et al., 1989; Craig et al., 1989), and some reports have correlated antibiotic resistance with transfer of plasmid DNA from $P$. haemolytica to $E$. coli by transformation (Zimmerman \& Hirsh, 1980; Livrelli et al., 1988; Schwarz et al., 1989; Craig et al., 1989) and back to $P$. haemolytica by conjugation (Craig et al., 1989). Previously, we investigated the transfer of a small plasmid encoding $A^{\mathrm{R}}$ between $P$. haemolytica strains by electroporation (Craig et al., 1989): Here we report the plasmid profiles exhibited by a range of $P$. haemolytica

* Author for correspondence. Tel. (041) 3304642 ; fax (041) 3304600. isolates and the inter- and intraspecies transfer of four plasmids which encoded $\beta$-lactam resistance. This resistance was shown in all cases to be due to $\beta$-lactamase activity of the ROB-1 type. Plasmid DNA was not readily detected in $E$. coli transformants by a routine plasmid isolation procedure but detection and amplification of these plasmids in $E$. coli was achieved by manipulating the growth conditions.

\section{Methods}

Bacterial strains, plasmids and growth media. The $P$. haemolytica strains used in this study were: 18 serotype Al strains, 15 of bovine origin (11 from pneumonic calves, 2 from animals in contact with pneumonic calves and 2 from healthy calves), 3 of ovine origin (from pneumonic sheep); 7 serotype A2 strains, 3 of bovine origin ( 2 from pneumonic calves and 1 from a healthy calf), 4 of ovine origin (from pneumonic sheep); 1 strain each from serotypes T4 and T10 from pneumonic sheep; 8 untypable strains ( 5 from pneumonic calves and 3 from pneumonic sheep). In addition, strain $A 2 S$ was used, which was a spontaneously derived streptomycin (Sm)-resistant mutant of $P$. haemolytica strain FA2 (serotype A2). E. coli strains and plasmids used are given in Table 1 .

All strains were stored frozen in $50 \%(\mathrm{v} / \mathrm{v})$ glycerol in brain heart 
Table 1. E. coli strains and plasmids used

\begin{tabular}{|c|c|c|}
\hline $\begin{array}{l}\text { Strain or } \\
\text { plasmid }\end{array}$ & Relevant characteristics & Reference \\
\hline \multicolumn{3}{|l|}{ E. coli } \\
\hline DH1/DH5 & $\begin{array}{l}\text { supE44 hsdRI7 recAl endAl } \\
\text { gyrA } 96 \text { thi-1 relAl }\end{array}$ & $\begin{array}{l}\text { Sambrook et al. } \\
\text { (1989) }\end{array}$ \\
\hline JM83 & $\begin{array}{l}\text { ara } \Lambda(\text { lac-proAB) rpsL } \phi 80 \alpha \\
\text { lac } Z \Delta \mathrm{M} 15\end{array}$ & $\begin{array}{l}\text { Vieira \& Messing } \\
\text { (1982) }\end{array}$ \\
\hline JC3272 & his lys trp & Achtman et al. (1971) \\
\hline $\mathrm{J} 53$ & pro met & $\begin{array}{l}\text { Meynell \& Datta } \\
(1966)\end{array}$ \\
\hline \multicolumn{3}{|l|}{ Plasmids } \\
\hline pRK2013 & $48 \mathrm{~kb}, \mathrm{Km}^{\mathrm{R}} \operatorname{Inc} \mathrm{P} \mathrm{Tra}^{+} \mathrm{ColE} 1$ & $\begin{array}{l}\text { Figurski \& Helinski } \\
\text { (1979) }\end{array}$ \\
\hline R6K & $\begin{array}{l}40 \mathrm{~kb}, \mathrm{Ap}^{\mathrm{R}}(\mathrm{TEM}-1) \\
\mathrm{Sm}^{\mathrm{R}} \operatorname{Tn} 2660 \operatorname{IncX} \mathrm{Tra}^{+}\end{array}$ & $\begin{array}{l}\text { Kontomichalou et al. } \\
\text { (1970) }\end{array}$ \\
\hline RP4 & $\begin{array}{l}54 \mathrm{~kb}, \mathrm{Ap}^{\mathrm{R}}(\mathrm{TEM}-2) \\
\mathrm{Km}^{\mathrm{R}} \mathrm{Tc}^{\mathrm{R}} \mathrm{Tn} / \mathrm{IncP} \mathrm{Tra}^{+}\end{array}$ & Datta et al. (1971) \\
\hline pRM3022 & $4.4 \mathrm{~kb}, \mathrm{Ap}^{R}(\mathrm{ROB}-1)$ & Rubin et al. (1981) \\
\hline $\mathrm{pPH} 2$ & $4.3 \mathrm{~kb}, \mathrm{Ap}^{\mathrm{R}}(\mathrm{ROB}-1)$ & This study \\
\hline pPH33 & $4.3 \mathrm{~kb}, \mathrm{Ap}^{\mathrm{R}}(\mathrm{ROB}-1)$ & This study \\
\hline pPH821 & $4.3 \mathrm{~kb}, \mathrm{Ap}^{\mathrm{R}}(\mathrm{ROB}-1)$ & This study \\
\hline pPH843 & $4.3 \mathrm{~kb}, \mathrm{Ap}^{\mathrm{R}}(\mathrm{ROB}-1)$ & This study \\
\hline
\end{tabular}

infusion (BHI) (Oxoid) broth at $-70^{\circ} \mathrm{C}$ and subcultured routinely on BHI agar medium with or without the supplementation of $5 \%(\mathrm{v} / \mathrm{v})$ defibrinated sheep blood (Becton Dickinson). Where necessary, antibiotic-resistant strains were grown on agar or in liquid media containing appropriate antibiotics. The concentrations of the antibiotics (Sigma) used in selective media were $\left(\mu \mathrm{g} \mathrm{ml}^{-1}\right)$; Ap (50), Sm (200), nalidixic acid ( $\mathrm{Nal})(20)$, kanamycin $(\mathrm{Km})(50)$, tetracycline $(\mathrm{Tc})$ (10) and $\mathrm{Cm}(25)$.

Determination of antibiotic resistance pattern, minimum inhibitory concentration (MIC) and $\beta$-lactamase production. Antibiotic resistance patterns of the $P$. haemolytica strains were determined by the diskdiffusion method (Barry \& Thornsberry, 1980) using cartridge-borne antibiotic disks and a multiple disk dispenser (Oxoid). Sixteen antibiotics were tested at the following concentrations per disk $(\mu \mathrm{g})$ : Ap (10), Cm (30), colistin sulphate (10), erythromycin (15), gentamicin (10), $\mathrm{Km}$ (30), lincomycin (Lm) (2), Nal (30), neomycin (30), nitrofurantoin (300), polymyxin B (300 I.U.), Sm (10), sulphonamide compound $(\mathrm{Su})(3300)$, sulphamethoxazole-trimethoprim (SXT) (25), Tc (30) and trimethoprim (Tp) (1-25). MICs of $\beta$-lactam antibiotics were determined by the agar-dilution method (Washington $\&$ Sutter, 1980 ) using Iso-sensitest agar media (Oxoid). The $\beta$-lactam antibiotics used were: Ap, penicillin G (Pe), carbenicillin (Carb), ticarcillin (Tic), cephalexin (Cex), cephalothin (Cet) and cephaloridine (Cer) (all from Sigma, except Carb which was from Beecham). The production of $\beta$ lactamase was tested by $\beta$-lactamase detection papers (Oxoid).

Preparation, purification and standardization of plasmid DNA. Plasmid DNA was extracted by the alkaline-lysis method (Sambrook et al., 1989). A single colony of $P$. haemolytica or $E$. coli from a fresh overnight-culture plate was inoculated into $10 \mathrm{ml} \mathrm{BHI}$ broth and incubated at $37^{\circ} \mathrm{C}$ on a rotary shaker for $18 \mathrm{~h}$. One $\mathrm{ml}$ of this culture was processed for miniprep plasmid DNA isolation. Plasmid DNA preparations were suspended in Tris/EDTA (TE) buffer $\left(\mathrm{g}^{-1}\right.$; Tris, $1.21 ; \mathrm{Na}_{2}$ EDTA, $0.37 ; \mathrm{pH} \mathrm{8.0)}$ and treated with pancreatic ribonuclease (Sigma) $\left(20 \mu \mathrm{g} \mathrm{ml}^{-1}\right.$ final concentration) at $37^{\circ} \mathrm{C}$ for $30 \mathrm{~min}$ before use. Plasmid DNA from large volumes of culture $(500-1000 \mathrm{ml})$ was extracted by the same method and purified by precipitation with polyethylene glycol (mol. mass 8000; Sigma) (Sambrook et al., 1989) followed by ammonium acetate $(2.5 \mathrm{M}$ final concentration) precipitation. The covalently closed circular (ccc) form of the plasmid DNA was then further purified by the acid-phenol extraction method of Zasloff et al. (1978) with the exception that $\mathrm{MgCl}_{2}$ (1.5 mM final concentration) was used instead of $\mathrm{NaCl}$ in the low ionic strength buffer. Gel electrophoresis was in $0.8 \%$ agarose (type II-A; Sigma) and Tris/borate/EDTA (TBE) buffer ( $\mathrm{g}^{-1}$; Tris, 10.78; boric acid, 5.5; $\mathrm{Na}$ EDTA, 0.744) in a horizontal submarine electrophoresis apparatus (GNA-100 or 200; Pharmacia). After electrophoresis, the gels were stained with ethidium bromide (Sigma) $\left(1 \mu \mathrm{g} \mathrm{m}^{-1}\right)$. Plasmid DNA size was estimated by reference to marker DNA (e.g. supercoiled DNA ladder from Gibco-BRL). The concentration of plasmid DNA was determined by comparison with known quantities of stained marker DNA (e.g. HindIII-digested $\lambda$ DNA from Gibco-BRL).

Transformation and conjugation. E. coli strains were transformed with plasmid DNA by the standard $\mathrm{CaCl}_{2}$-procedure (Sambrook et al., 1989). Conjugation was by the plate-mating method as described previously (Craig et al., 1989), with the exception that overnight cultures instead of exponential-phase cultures of donor, recipient and/or helper strains were used and with mating for $6 \mathrm{~h}$ (E. coli recipient) or $16 \mathrm{~h}(P$. haemolytica recipient) instead of $1 \mathrm{~h}$. Plasmid pRK2013 was used as the helper plasmid to supply $I n c P$ conjugative transfer functions. Transconjugant-selection plates were incubated for $18 \mathrm{~h}$ (E. coli recipient) or $48 \mathrm{~h}$ ( $P$. haemolytica recipient).

Amplification of plasmid DNA. E. coli transformants were grown in BHI broth, nutrient broth (Oxoid), Luria-Bertani (LB) broth $\left(\mathrm{g} \mathrm{l}^{-1}\right.$; tryptone, 10 ; yeast extract, $5 ; \mathrm{NaCl}, 10)$, Terrific broth $\left(\mathrm{g} \mathrm{l}^{-1}\right.$; tryptone, 12; yeast extract, 24 ; glycerol, $4 \mathrm{ml} ; \mathrm{KH}_{2} \mathrm{PO}_{4}, 2 \cdot 31 ; \mathrm{K}_{2} \mathrm{HPO}_{4}, 12.54$ ) (Tartof \& Hobbs, 1987) or in Terrific broth supplemented with $1 \%$ $(\mathrm{w} / \mathrm{v})$ yeast nitrogen base (YNB) (Difco) for 6-7 h to late exponential phase $\left(\mathrm{OD}_{600} \sim 0 \cdot 6\right)$. A 0.1 volume was inoculated into corresponding fresh broth and incubated with vigorous shaking at $37^{\circ} \mathrm{C}$ for $2.5-3.0 \mathrm{~h}$ $\left(\mathrm{OD}_{600} \sim 0 \cdot 4\right)$. At this stage, $\mathrm{Cm}\left(170 \mu \mathrm{g} \mathrm{ml}^{-1}\right.$ final concentration) (Clewell, 1972) or Tc $\left(15 \mu \mathrm{g} \mathrm{ml}^{-1}\right.$ final concentration) was added and incubation continued for a further 14-15 h. Ampicillin selection was maintained throughout growth and the $\mathrm{OD}_{600}$ noted before the cells were used for preparation of plasmid DNA.

Restriction endonuclease analysis. Restriction endonuclease enzymes were purchased from Gibco-BRL, Stratagene or Boehringer Mannheim and used according to the manufacturers' instructions. Restriction fragments were separated by electrophoresis on $1 \cdot 8-2 \%$ agarose.

Southern hydridization. A Sau 3 AI digest of plasmid pPH 843 was used as a probe for hybridization to Sau3AI-digested fragments of the prototype ROB-1 plasmid pRM3022 transferred to Hybond-N membrane (Amersham). DNA fragments were labelled to high specific activity with $\left[\alpha^{-32} \mathrm{P}\right] \mathrm{dATP}$ (Amersham) by the random priming technique (Feinberg \& Vogelstein, 1984). Hybridizations were performed at $42{ }^{\circ} \mathrm{C}$ in the presence of $50 \%(\mathrm{v} / \mathrm{v})$ formamide and blots were washed in $1 \times \mathrm{SSC}, 0 \cdot 1 \% \mathrm{SDS}$ at $60^{\circ} \mathrm{C}$ for $2 \mathrm{~h}$ prior to autoradiography.

$\beta$-Lactamase assay. $\beta$-Lactamase activity was assayed by the macroiodometric method of Ross \& O'Callaghan (1975) on crude sonic extracts of $E$. coli cells grown overnight with shaking in 1 litre of BHI broth in the presence of $\mathrm{Ap}\left(50 \mu \mathrm{g} \mathrm{ml}^{-1}\right)$. Cells were pelleted, washed in potassium phosphate buffer $(\mathrm{pH} 7 \cdot 0$ ), and sonicated in the same buffer $(4 \times 30 \mathrm{~s}$ with $30 \mathrm{~s}$ intervals on ice) with an ultrasonic disintegrator (MSE). Supernates were collected after centrifugation at $140000 \mathrm{~g}$ for $1 \mathrm{~h}$ at $4{ }^{\circ} \mathrm{C}$, dialysed overnight at $4{ }^{\circ} \mathrm{C}$ against deionized distilled water, and concentrated by freeze-drying. Freeze-dried samples were reconstituted with phosphate buffer before use. Penicillin G, Ap, Carb, oxacillin (Oxa), cloxacillin (Clox), Cer, Cet and Cex were used as substrates to measure the rate of $\beta$-lactam hydrolysis. Inhibition of $\beta$ lactamase activity, either by $100 \mathrm{~mm}-\mathrm{NaCl}$ or $0.1 \mathrm{mM}-\mathrm{Clox}$, was carried 


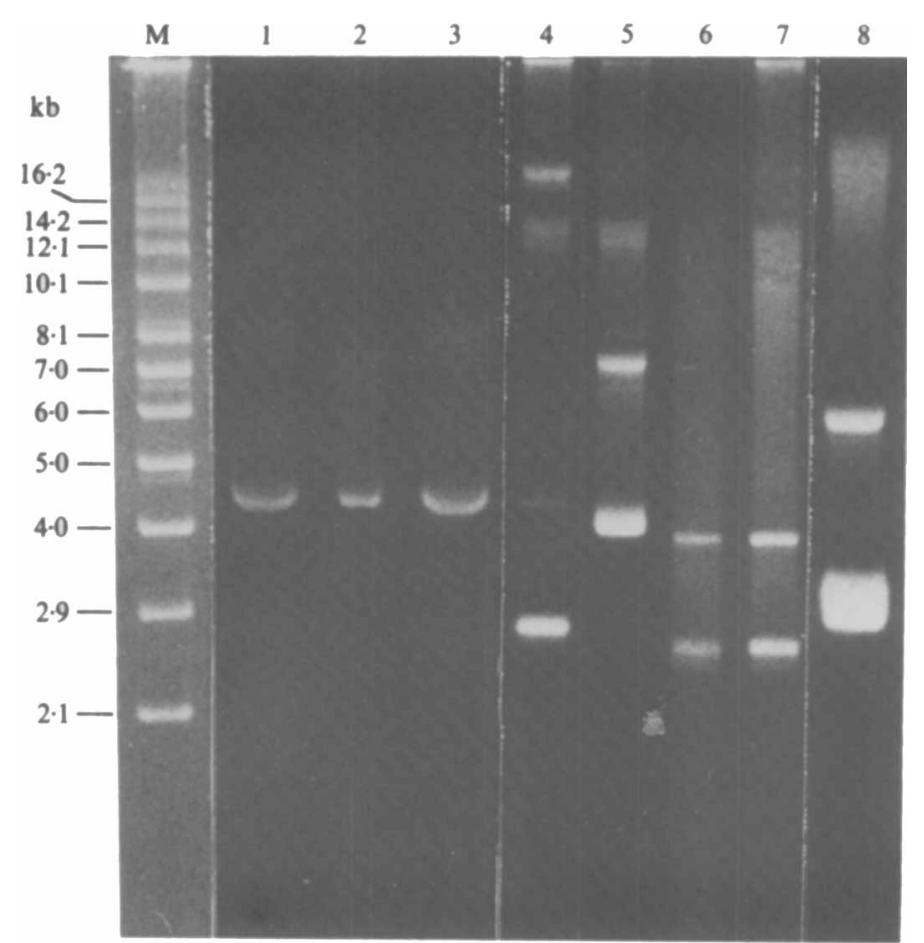

Fig. 1. Agarose gel $(0.8 \%)$ electrophoresis of plasmid DNA preparations from $P$. haemolytica serotype A1 strains: B2070 (lane 1), CVL33 (lane 2), S/C 82/1 (lane 3), S/C 84/3 (lane 4); serotype A2 strains: B664 (lane 5), D/I 85/1 (lane 6), G/T 85/15 (lane 7) and untypable strain T1368 (lane 8). Supercoiled DNA ladder was used as the marker DNA (lane $M$ ). The figure is a composite of three separate gels run under identical conditions with the marker DNA in each. The two smaller plasmids of strain T1368 (lane 8) are not clearly separated in this figure. The diffuse staining regions in lanes $4,5,7$ and 8 are assumed to represent chromosomal DNA. out with $\mathrm{Pe}$ as substrate. Inhibitors were added to enzyme suspensions before addition of Pe. Protein content of the enzyme preparations was estimated by the Bradford assay (Bradford, 1976) using bovine serum albumin as standard, and specific activity of the $\beta$-lactamases was expressed as $\mu \mathrm{mol} \mathrm{min}^{-1}$ (mg protein) ${ }^{-1}$.

Analytical isoelectric focusing. Analytical isoelectric focusing was performed at a constant power of $1 \mathrm{~W}$ for $4 \mathrm{~h}$ on Ampholine PAG plates (pH 3.5-9.5) (Pharmacia LKB) with an LKB Multiphor apparatus. The test samples were sonic extracts of $E$. coli containing either the $\beta$-lactamase-encoding plasmids from $P$. haemolytica or the known TEM- and ROB-type $\beta$-lactamase-encoding plasmids. The gel was stained with nitrocefin $\left(0.5 \mathrm{mg} \mathrm{m}^{-1}\right)$ (Oxoid) for detection of $\beta$ lactamase activity and photographed as described previously (Matthew et al., 1975). Isoelectric points (pIs) of unknown $\beta$-lactamases were determined by reference to those of known $\beta$-lactamases.

\section{Results}

\section{Antibiotic resistance and plasmid profiles of $P$. haemolytica strains}

All $35 P$. haemolytica strains showed resistance to $\mathrm{Lm}$, $\mathrm{Sm}$ and $\mathrm{Su}$. In addition, some strains were resistant to SXT, Tp, Tc, Ap and Cm. Plasmid analysis revealed the presence of plasmid DNA in eight of the strains (Fig. 1). The plasmid contents of these strains and their antibiotic resistance phenotypes are given in Table 2 . A $4.3 \mathrm{~kb}$ plasmid was present in each of the four serotype Al strains. Strain S/C 84/3 additionally contained two other plasmids of approximately $20 \mathrm{~kb}$ and $2.8 \mathrm{~kb}$. The three serotype A2 strains each appeared to contain two plasmids; two strains had similar plasmid profiles $(\sim 4.0$ and $2.7 \mathrm{~kb}$ ) whilst in the third strain the $2.7 \mathrm{~kb}$ plasmid was replaced by a $7.6 \mathrm{~kb}$ plasmid. The untypable strain had three plasmids, all apparently different from those of the A1 and A2 strains. Neither the T4 nor the T10 serotype strain appeared to contain plasmid DNA. Since the $\mathrm{Lm}, \mathrm{Sm}$ and $\mathrm{Su}$ resistances were common to all the strains of $P$. haemolytica, it is unlikely that they are plasmid-mediated. Since these were the only resistances exhibited by the plasmid-carrying A2 and untypable strains, no resistance phenotype can be ascribed to their plasmids. The plasmid-carrying Al strains were $A p^{R}$ and $T c^{R}$, and also $\mathrm{Cm}^{R}$ in the case of strain $\mathrm{S} / \mathrm{C} \mathrm{84/3}$, and these were candidate resistances for carriage by these plasmids. However, $\mathrm{Tc}^{\mathrm{R}}$ was also exhibited by two plasmid-less Al strains.

Transformation of E. coli with P. haemolytica Al plasmid DNA

Plasmid DNA from A1 strains B2070, CVL33, S/C 82/1 and $\mathrm{S} / \mathrm{C} 84 / 3$ was used to transform $E$. coli strain $\mathrm{DH} 1$ selecting separately for $A p^{R}, T c^{R}$ and, in the case of $S / C$ $84 / 3, \mathrm{Cm}^{\mathrm{R}}$ transformants. Only $\mathrm{Ap}^{\mathrm{R}}$ transformants were obtained. Transformation frequencies were similar with plasmid DNA preparations from strains B2070, CVL33 and $\mathrm{S} / \mathrm{C} 82 / 1,0 \cdot 7-1.3 \times 10^{6}$ transformants per $\mu \mathrm{g}$ plas- 
Table 2. Plasmid profiles of $P$. haemolytica strains and their antibiotic resistance phenotypes

\begin{tabular}{|c|c|c|c|c|}
\hline $\begin{array}{c}\text { Serotype } \\
\left(n=\begin{array}{c}\text { no. of strains } \\
\text { tested })\end{array}\right.\end{array}$ & $\begin{array}{l}\text { Animal source } \\
\text { (health status) }\end{array}$ & $\begin{array}{l}\text { Strain no. } \\
\text { (positive for } \\
\text { plasmid) }\end{array}$ & $\begin{array}{c}\text { Antibiotic } \\
\text { resistance } \\
\text { phenotypes* }\end{array}$ & $\begin{array}{l}\text { Plasmid } \\
\text { (kb) }\end{array}$ \\
\hline \multirow[t]{4}{*}{ Al $(n=18)$} & $\begin{array}{c}\text { Bovine } \\
\text { (pneumonic) }\end{array}$ & B2070 & Ap, Tc & $4 \cdot 3$ \\
\hline & $\begin{array}{c}\text { Bovine } \\
\text { (pneumonic) }\end{array}$ & CVL33 & Ap, Tc & $4 \cdot 3$ \\
\hline & $\begin{array}{c}\text { Bovine } \\
\text { (pneumonic) }\end{array}$ & $\mathrm{S} / \mathrm{C} 82 / 1$ & Ap, Tc & $4 \cdot 3$ \\
\hline & $\begin{array}{c}\text { Bovine } \\
\text { (in-contact) }\end{array}$ & $\mathrm{S} / \mathrm{C} 84 / 3$ & $\mathrm{Ap}, \dagger \mathrm{Tc}, \mathrm{Cm}$ & $\sim 20,4 \cdot 3,2 \cdot 8$ \\
\hline \multirow[t]{3}{*}{$\mathrm{A} 2(n=7)$} & $\begin{array}{c}\text { Ovine } \\
\text { (pneumonic) }\end{array}$ & B664 & None & $7 \cdot 6,4 \cdot 0$ \\
\hline & $\begin{array}{c}\text { Bovine } \\
\text { (pneumonic) }\end{array}$ & $\mathrm{D} / \mathrm{I} 85 / 1$ & None & $3.9,2.7$ \\
\hline & $\begin{array}{l}\text { Bovine } \\
\text { (healthy) }\end{array}$ & G/T $85 / 15$ & None & $3 \cdot 9,2 \cdot 7$ \\
\hline Untypable $(n=8)$ & $\begin{array}{c}\text { Ovine } \\
\text { (pneumonic) }\end{array}$ & T1368 & None & $5 \cdot 9,3 \cdot 1,2 \cdot 9$ \\
\hline
\end{tabular}

* All 35 strains (including the two T4 and T10 strains) tested by the disk-diffusion method were resistant to $\mathrm{Lm}, \mathrm{Sm}$ and $\mathrm{Su}$.

$\dagger$ Partially resistant, as observed by partial inhibition of growth.

Table 3. Mobilization frequencies of $P$. haemolytica $A p^{\mathbf{R}}$ plasmids from $E$. coli transformants to $P$. haemolytica and $E$. coli recipients by conjugation

\begin{tabular}{|c|c|c|c|}
\hline $\begin{array}{l}\text { E. coli donor } \\
\text { strain }\end{array}$ & $\begin{array}{l}\text { Helper } \\
\text { plasmid* }\end{array}$ & $\begin{array}{c}\text { Recipient } \\
\text { strain } \dagger\end{array}$ & $\begin{array}{c}\text { Mobilization frequency } \\
\text { (transconjugants per recipient) } \ddagger\end{array}$ \\
\hline DH1(pPH2) & pRK2013 & $\begin{array}{ll}\text { A2S } & \text { Ph } \\
\text { JC3272 Ec }\end{array}$ & $\begin{array}{l}1 \cdot 2( \pm 0.3) \times 10^{-5} \\
2 \cdot 8( \pm 0 \cdot 5) \times 10^{-4}\end{array}$ \\
\hline DH1(pPH33) & pRK2013 & $\begin{array}{ll}\mathrm{A} 2 \mathrm{~S} & \mathrm{Ph} \\
\mathrm{JC} 3272 \mathrm{Ec}\end{array}$ & $\begin{array}{l}1.3( \pm 0.5) \times 10^{-5} \\
3.3( \pm 0.6) \times 10^{-4}\end{array}$ \\
\hline DH1(pPH821) & pRK2013 & $\begin{array}{ll}\text { A2S } & \text { Ph } \\
\text { JC3272 Ec }\end{array}$ & $\begin{array}{l}1 \cdot 3( \pm 0 \cdot 4) \times 10^{-5} \\
3 \cdot 4( \pm 0 \cdot 7) \times 10^{-4}\end{array}$ \\
\hline DH1(pPH843) & pRK2013 & $\begin{array}{ll}\mathrm{A} 2 \mathrm{~S} & \mathrm{Ph} \\
\mathrm{JC} 3272 \mathrm{Ec}\end{array}$ & $\begin{array}{l}4.4( \pm 0.4) \times 10^{-4} \\
1 \cdot 3( \pm 0 \cdot 2) \times 10^{-1}\end{array}$ \\
\hline
\end{tabular}

${ }^{*}$ E. coli DH5 $\left(\mathrm{Nal}^{\mathrm{R}}\right)$ was used as the carrier of the helper plasmid when $\mathrm{Sm}^{\mathrm{R}}$ recipient strains (A2S and JC3272) were used. Transconjugants were selected on BHI agar with Ap $+\mathrm{Sm}$. Recipient cell numbers were calculated by plating appropriate dilutions on BHI agar containing $\mathrm{Sm}$.

$\dagger \mathrm{Ph}, P$. haemolytica; Ec, E. coli.

$\ddagger$ Each value shown is the mean $( \pm \mathrm{SEM})$ of observations from three separate experiments.

mid DNA, but were noticeably lower with that from strain $\mathrm{S} / \mathrm{C} 84 / 3$, presumably because the presence of other species of plasmid DNA reduced the apparent transformation frequency. Similar results were obtained with $E$. coli JM83 as recipient. Plasmid DNA was not detected in $E$. coli transformants and their presence was only confirmed by transformation of $E$. coli again to $\mathrm{Ap}^{\mathrm{R}}$ with the plasmid DNA preparations. The $A p^{R}$-encoding plasmids from $P$. haemolytica strains B2070, CVL33,
S/C 82/1 and S/C 84/3 were designated pPH2, pPH33, pPH821 and pPH843 respectively.

Mobilization of $P$. haemolytica plasmids from $E$. coli to $P$. haemolytica and E. coli by conjugation

Plasmid transfer from $P$. haemolytica strains B2070, CVL33, S/C 82/1 or S/C 84/3 to either $P$. haemolytica or 


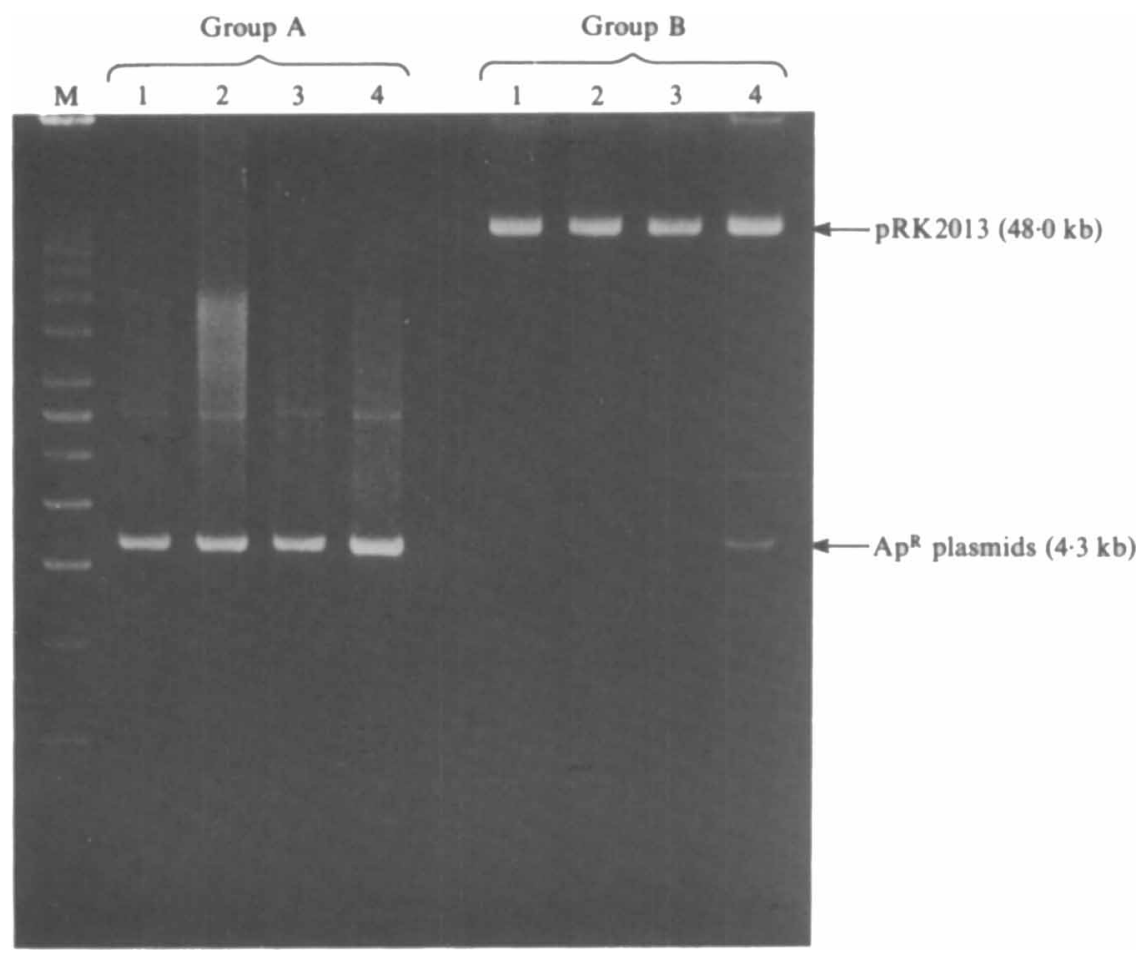

Fig. 2. Agarose gel $(0 \cdot 8 \%)$ electrophoresis of plasmid DNA preparations from $P$. haemolytica and $E$. coli $\mathrm{Ap}^{R}$ transconjugants. $P$. haemolytica Al Ap ${ }^{R}$ plasmids (all $4.3 \mathrm{~kb}$ ) pPH2 (lane 1), pPH33 (lane 2), pPH821 (lane 3) and pPH843 (lane 4) are seen in $P$. haemolytica A2S transconjugants (group A), but only pPH843 is visible in E. coli JC3272 transconjugants (group B). The helper plasmid pRK2013 $(48.0 \mathrm{~kb})$ used in conjugation is shown by $E$. coli transconjugants, but not by $P$. haemolytica transconjugants. Lane $M$ represents a supercoiled DNA ladder. The upper faint band present in all lanes of group $A$ probably represents an open circular (oc) form of the $4.3 \mathrm{~kb}$ plasmid.

Table 4. $\beta$-Lactamase profile and MICs of $\beta$-lactam antibiotics for plasmid-containing Ap ${ }^{\mathrm{R}}$ strains For abbreviations of $\beta$-lactam antibiotics, see Methods.

\begin{tabular}{|c|c|c|c|c|c|c|c|c|}
\hline \multirow[b]{2}{*}{ Strain } & \multirow{2}{*}{$\begin{array}{c}\beta- \\
\text { Lactamase }\end{array}$} & \multicolumn{7}{|c|}{$\operatorname{MIC}\left(\mu \mathrm{g} \mathrm{ml}^{-1}\right)$} \\
\hline & & $\mathrm{Pe}$ & Ap & Carb & Tic & Cex & Cet & Cer \\
\hline \multicolumn{9}{|l|}{ P. haemolytica } \\
\hline B2070 & + & 64 & 64 & 64 & 16 & 2 & 4 & 2 \\
\hline CVL33 & + & 128 & 128 & 128 & 32 & 2 & 4 & 2 \\
\hline $\mathrm{S} / \mathrm{C} 82 / 1$ & + & 64 & 64 & 64 & 16 & 2 & 4 & 2 \\
\hline $\mathrm{S} / \mathrm{C} 84 / 3$ & - & 2 & 1 & $0 \cdot 5$ & 0.5 & 2 & 4 & 1 \\
\hline A2S (plasmid-free) & - & $<0.25$ & $<0 \cdot 25$ & $<0.25$ & $<0.25$ & 1 & $<0.25$ & $<0.25$ \\
\hline $\left.\begin{array}{l}\mathrm{A} 2 \mathrm{~S}(\mathrm{pPH} 2), \mathrm{A} 2 \mathrm{~S}(\mathrm{pPH} 33) \\
\text { and } \mathrm{A} 2 \mathrm{~S}(\mathrm{pPH} 2 \mathrm{I})\end{array}\right\}^{*}$ & + & 128 & 64 & 256 & 32 & 2 & 4 & 2 \\
\hline $\mathrm{A} 2 \mathrm{~S}(\mathrm{pPH} 843)^{*}$ & + & 256 & 128 & 256 & 64 & 2 & 4 & 2 \\
\hline \multicolumn{9}{|l|}{ E. coli } \\
\hline DHI (plasmid-free) & - & 4 & 2 & 2 & 1 & 4 & 2 & 1 \\
\hline $\left.\left.\begin{array}{l}\mathrm{DHI}(\mathrm{pPH} 2), \mathrm{DH} 1(\mathrm{pPH} 33) \\
\text { and } \mathrm{DH} 1(\mathrm{pPH} 821)\end{array}\right\}\right\}^{\dagger}$ & $\pm \ddagger$ & 2048 & 1024 & $>2048$ & 2048 & 16 & 1024 & 16 \\
\hline DH $1(\mathrm{pPH} 843) \dagger$ & + & $>2048$ & $>2048$ & $>2048$ & $>2048$ & 128 & 2048 & 128 \\
\hline DHI(RP4) & + & $>2048$ & $>2048$ & $>2048$ & $>2048$ & 8 & 32 & 32 \\
\hline DHI(pRM3022) & + & 2048 & 2048 & $>2048$ & $>2048$ & 32 & 64 & 64 \\
\hline
\end{tabular}

* Transconjugants; $†$ transformants; $\ddagger$ weakly positive.

$E$. coli by conjugation was unsuccessful, either in the presence or absence of the broad-host-range helper plasmid pRK2013. The large plasmid present in S/C 84/3 was therefore not able to mobilize either of the two smaller plasmids present in that strain. However, the plasmids could be mobilized from $E$. coli $\mathrm{DH} 1$ into both $P$. haemolytica $\mathrm{A} 2 \mathrm{~S}$ and $E$. coli $\mathrm{JC} 3272$ by using the transfer functions of pRK2013 (Table 3). No transconju- gants were obtained in the absence of the helper plasmid. The mobilization frequency into $E$. coli was noticeably higher than into $P$. haemolytica.

Interestingly, plasmid pPH843 was mobilized with the highest frequency into $E$. coli $\mathrm{JC} 3272$ by conjugation, yet showed the lowest transformation frequency into $E$. coli DH1. Plasmid profiles of all transconjugants of $\boldsymbol{P}$. haemolytica A2S (Fig. 2) showed the presence of a 
Table 5. Substrate and inhibition profiles, and specific activities of E. coli extracts containing $\beta$-lactamases encoded by plasmids pPH2, pPH33, pPH821 and pPH843 compared with those of TEM-and ROB-type $\beta$-lactamases

For abbreviations of $\beta$-lactam antibiotics, see Methods. Values are the means of two independent determinations.

\begin{tabular}{|c|c|c|c|c|c|c|c|c|c|c|}
\hline \multirow{3}{*}{$\begin{array}{c}\text { Plasmid } \\
\text { ( } \beta \text {-lactamase } \\
\text { type })\end{array}$} & \multirow{2}{*}{\multicolumn{7}{|c|}{ Relative rate of hydrolysis $(\%)^{*}$}} & \multirow{3}{*}{$\begin{array}{c}\text { Specific } \\
\text { activity }\end{array}$} & \multicolumn{2}{|c|}{$\begin{array}{c}\text { Percentage } \\
\text { activity in } \\
\text { presence of }: \ddagger\end{array}$} \\
\hline & & & & & & & & & $\mathrm{NaCl}$ & Clox \\
\hline & Ap & Carb & Oxa & Clox & Cer & Cet & Cex & & $(100 \mathrm{mM})$ & $(0 \cdot 1 \mathrm{mM})$ \\
\hline R6K (TEM-1) & 115 & 13 & 7 & 2 & 168 & 15 & 11 & $6 \cdot 8$ & 98 & 80 \\
\hline RP4 (TEM-2) & 117 & 14 & 5 & $<2$ & 166 & 15 & 10 & $49 \cdot 6$ & 98 & 75 \\
\hline pRM3022 (ROB-1) & 189 & 29 & 2 & 0 & 42 & 4 & 37 & $13 \cdot 0$ & 100 & 32 \\
\hline $\mathrm{pPH} 2$ & 178 & 31 & 2 & 0 & 40 & 6 & 38 & 0.8 & 100 & 41 \\
\hline pPH33 & 185 & 32 & 2 & 0 & 43 & 4 & 33 & 0.76 & 100 & 36 \\
\hline pPH821 & 187 & 32 & 2 & 0 & 42 & 5 & 33 & 0.6 & 100 & 38 \\
\hline pPH843 & 196 & 27 & 2 & 0 & 38 & 4 & 30 & $10 \cdot 0$ & 100 & 28 \\
\hline
\end{tabular}

* Activity relative to activity against penicillin $\mathrm{G}$ (defined as $100 \%$ ).

$\dagger$ Expressed as $\mu \mathrm{mol} \mathrm{min}^{-1}$ (mg protein) ${ }^{-1}$ with penicillin $\mathbf{G}$ as substrate.

$\ddagger$ Expressed as a percentage of the activity against penicillin $G$ in the presence of inhibitor.

predominant $4.3 \mathrm{~kb}$ band, but a band of similar size was visible only in transconjugants of $E$. coli JC3272 containing plasmid pPH843. This confirms that the $4.3 \mathrm{~kb}$ plasmid present in the original strain $\mathrm{S} / \mathrm{C} 84 / 3$ (Table 2) encoded $A p^{R}$. E. coli transconjugants showed the presence of plasmid pRK2013, which was not shown by $P$. haemolytica transconjugants (Fig. 2) as pRK2013 is a ColEl-based replicon which does not replicate in $P$. haemolytica.

\section{MICs of $\beta$-lactam antibiotics for plasmid-bearing $P$. haemolytica and E. coli strains}

The MICs of $\beta$-lactam antibiotics correlated well for the original $P$. haemolytica isolates and the $\mathrm{Ap}^{\mathrm{R}}$ transconjugant strains of $P$. haemolytica A2S (Table 4). Wild-type isolate $\mathrm{S} / \mathrm{C} 84 / 3$ was $\beta$-lactamase-negative and showed much lower MIC values for those antibiotics to which the other three original isolates were clearly resistant. However, strain A2S(pPH843), which contains plasmid pPH843 from strain S/C 84/3, exhibited a MIC profile similar to that of the other transconjugants. The MICs for both the penicillin and cephalosporin groups of antibiotics were markedly increased in each of the $E$. coli DH1 transformants, representing an 8- to 256-fold increase for transformants with plasmids pPH2, pPH33 and pPH821, and a 64- to $>4096$-fold increase for transformants with plasmid pPH843, over those values obtained with the original $P$. haemolytica hosts. The TEM-type $\beta$-lactamase plasmid RP4 and the ROB-type $\beta$-lactamase plasmid pRM3022 contained in E. coli DH1 were used for a comparison with the $P$. haemolytica plasmids in the same E. coli strain. Similar MIC profiles for the penicillin group and somewhat different profiles for the cephalosporin group were obtained when $E$. coli containing either type of the known $\beta$-lactamase plasmids was compared with $E$. coli containing the $P$. haemolytica plasmids.

\section{$\beta$-Lactamase characterization}

Table 5 shows the substrate and inhibition profiles, and specific activities of the plasmid-mediated $P$. haemolytica $\beta$-lactamases extracted from $E$. coli $\mathrm{DH} 1$ transformants. The prototype TEM-1 from $E$. coli strain J53(R6K), TEM-2 from DH1(RP4) and ROB-1 from DH1(pRM3022) were used as the reference $\beta$-lactamases. The TEM- and ROB-type enzymes can be distinguished by their different activities against penicillins and cephalosporins as well as by their pI values (Rubin et al., 1981; Medeiros et al., 1986). The substrate and inhibition profiles of $\beta$-lactamases produced by $P$. haemolytica plasmids pPH2, pPH33, pPH821 and pPH843 were very similar to those exhibited by the prototype ROB-1 (Table 5). As analysed by isoelectric focusing, the main bands of $\beta$-lactamase activity produced by these plasmids (Fig. 3, lanes 4-7) focused at the same pI (8.1) as the prototype ROB-1 activity (lane 3), while the TEM- 1 and TEM- 2 enzymes focused at pIs 5.4 and 5.6 respectively (lanes 1 and 2). The accompanying bands in lanes 1 and 2, and an additional band (pI 8.0) common to all enzyme preparations, probably represent 


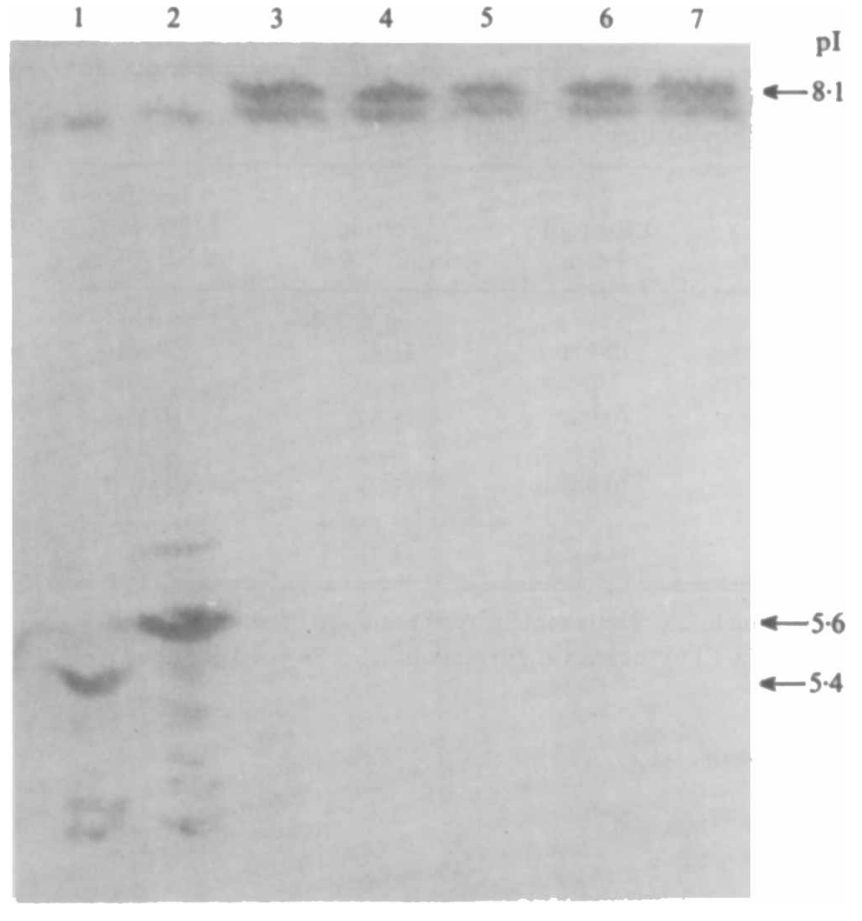

Fig. 3. Comparative analytical isoelectric focusing patterns of $E$. coli extracts containing known $\beta$ lactamases and those encoded by the $P$. haemolytica plasmids. Lane 1, TEM-1 (pI 5.4); lane 2, TEM-2 (pI 5.6); lane 3, ROB-1 (pI 8.1) (Medeiros et al., 1985). The $\beta$-lactamases produced by plasmids pPH 2 (lane 4), pPH33 (lane 5), pPH821 (lane 6) and pPH843 (lane 7) are seen at the same pI as the ROB-1 enzyme. A common additional band (pI 8.0) representing the chromosomally determined $\beta$-lactamase of $E$. coli is seen in all lanes. At least 10 times concentrated enzyme preparations from strains containing $\mathrm{pPH} 2, \mathrm{pPH} 33$ and $\mathrm{pPH} 821$ compared to the preparation from the strain containing pPH843 were loaded onto the gel.

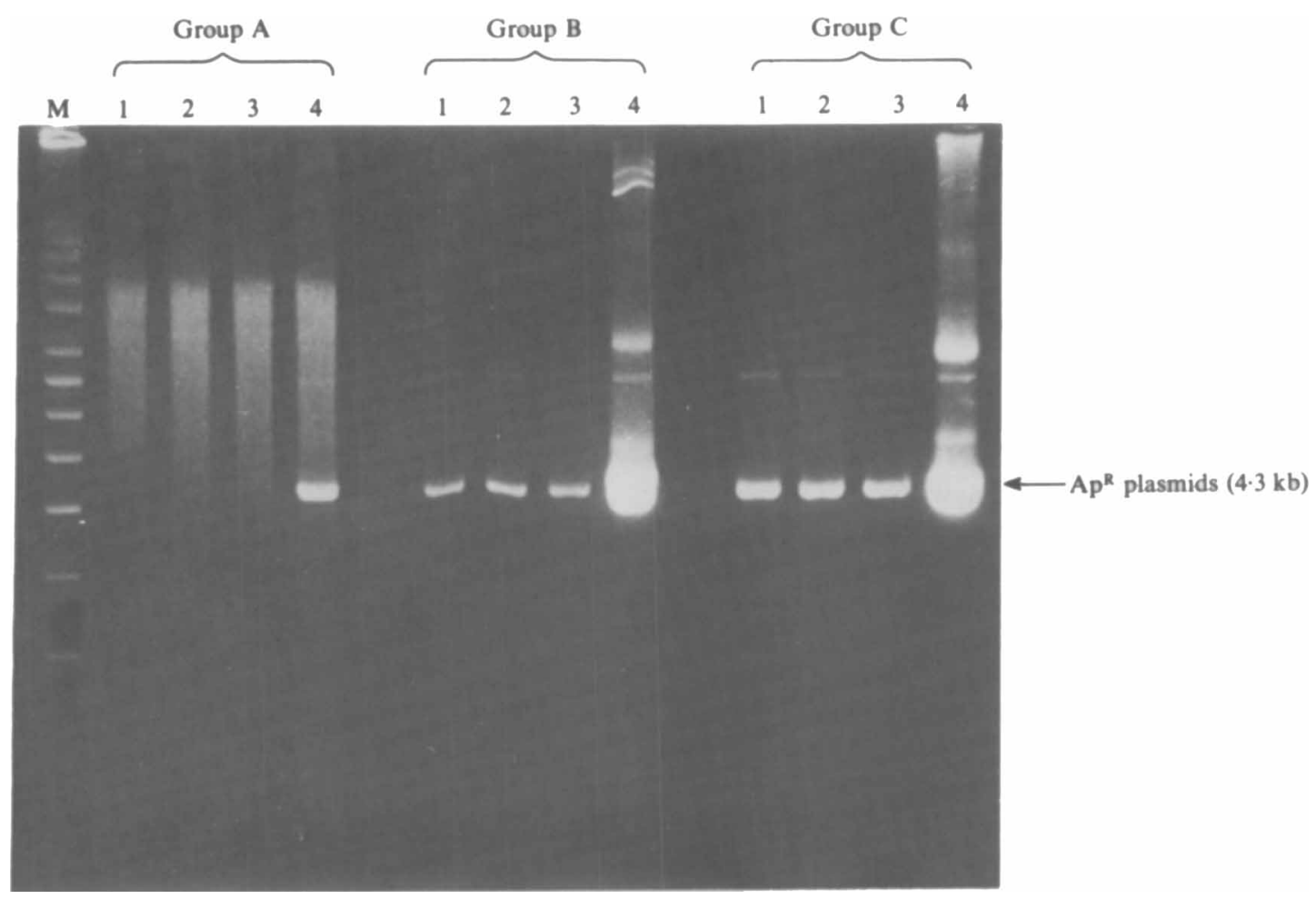

Fig. 4. Agarose gel (0.8\%) showing the yields of P. haemolytica Ap ${ }^{\mathrm{R}}$ plasmids pPH2 (lane 1), pPH33 (lane 2), pPH821 (lane 3), and pPH843 (lane 4) from $E$. coli DHI transformants after amplification procedures. The $E$. coli transformants were grown in Terrific broth alone (group A), or Terrific broth $+\mathrm{Cm}$ (group B) or Terrific broth $+1 \% \mathrm{YNB}+\mathrm{Cm}$ (group C). $\mathrm{M}$, supercoiled DNA ladder. The additional upper band(s) (groups $B$ and $C$ ) probably represent oc forms and/or dimers of the $4.3 \mathrm{~kb}$ plasmid. 
Table 6. Effects of amplification procedures on P. haemolytica plasmid DNA in E. coli DHI

\begin{tabular}{|c|c|c|c|c|c|c|}
\hline \multirow[b]{2}{*}{$\begin{array}{c}\mathrm{Ap}^{R} \\
\text { plasmid }\end{array}$} & \multicolumn{6}{|c|}{$\begin{array}{l}\text { Extent of amplification under different growth conditions* } \\
\left(\mathrm{OD}_{600} \text { of culture at time of harvest) }\right.\end{array}$} \\
\hline & $\begin{array}{c}\text { Broth } \\
\text { medium } \\
\text { alone }\end{array}$ & $\begin{array}{l}\text { BHI broth } \\
+\mathrm{Cm}\end{array}$ & $\begin{array}{c}\text { Nutrient } \\
\text { broth }+\mathrm{Cm}\end{array}$ & $\begin{array}{l}\text { LB broth } \\
+\mathrm{Cm}\end{array}$ & $\begin{array}{c}\text { Terrific } \\
\text { broth }+\mathrm{Cm}\end{array}$ & $\begin{array}{c}\text { Terrific } \\
\text { broth }+1 \% \\
\text { YNB }+\mathrm{Cm}\end{array}$ \\
\hline pPH2 & $(\leqslant 2 \cdot 48)$ & $\overline{(1 \cdot 3)}$ & $(0 . \overline{84})$ & $\stackrel{+}{(0.97)}$ & $\begin{array}{c}++ \\
(1 \cdot 4)\end{array}$ & $\begin{array}{l}+++ \\
(1.53)\end{array}$ \\
\hline pPH33 & $(\leqslant \overline{2} \cdot 48)$ & $(\overline{1.4)}$ & $\begin{array}{c}- \\
(0.84)\end{array}$ & $\stackrel{+}{+}$ & $\begin{array}{c}++ \\
(1 \cdot 32)\end{array}$ & $\begin{array}{l}+++ \\
(1.35)\end{array}$ \\
\hline pPH821 & $(\leqslant 2 \cdot 46)$ & $(\overline{1 \cdot 3})$ & $(0.83)$ & $\stackrel{+}{+}$ & $\begin{array}{c}++ \\
(1 \cdot 3)\end{array}$ & $\begin{array}{l}+++ \\
(1 \cdot 4)\end{array}$ \\
\hline pPH843 & $\begin{array}{l}+/++\ddagger \\
(\leqslant 2 \cdot 49)\end{array}$ & $\begin{array}{l}+++ \\
(1.68)\end{array}$ & $\begin{array}{l}+++ \\
(0.92)\end{array}$ & $\underset{(1.0)}{+++}$ & $\underset{(1.7)}{+t+t}$ & $\begin{array}{c}++t+ \\
(1.8)\end{array}$ \\
\hline
\end{tabular}

* Grading of plasmid DNA amplification was done according to the relative intensity of ethidium bromide staining of plasmid DNA in agarose gels, ranging from a detectable level $(+)$ to the maximum amount $(+++++)$ obtained; indicates 'not detectable'.

+ BHI broth, Nutrient broth, LB broth or Terrific broth

$\ddagger$ Detectable in LB broth only and amplified in Terrific broth.

variant, satellite bands and the chromosomal $\beta$-lactamase of $E$. coli, respectively, as reported by Matthew et al. (1975) and Medeiros et al. (1985). The $\beta$-lactamase produced by the plasmid pPH843 showed a higher specific activity in $E$. coli than those produced by the other three $P$. haemolytica plasmids (Table 5). This is probably related to plasmid copy number as pPH843 was the only plasmid DNA visible in preparations from E. coli (Fig. 2B lane 4).

\section{Amplification of P. haemolytica plasmid DNA in E. coli}

As each $A p^{R}$ plasmid apparently had a low copy number in $E$. coli, attempts were made to amplify the plasmid DNA in E. coli transformants. DH1 transformants were grown in various nutrient media with or without the addition of $\mathrm{Cm}$ and the influence of culture conditions on the yield of the $\mathrm{Ap}^{\mathrm{R}}$ plasmids was observed (Table 6). Changes in growth media alone affected the yield of plasmid pPH843, which was detected in LB broth and amplified in Terrific broth. This plasmid was, in addition, further amplified when exposed to $\mathrm{Cm}$ in any broth medium used, although Terrific broth gave the highest yield (Table 6; Fig. 4). Amplification was only evident with the other three plasmids (pPH2, pPH33 and pPH821) when the host strains were grown in LB or Terrific broth in the presence of $\mathrm{Cm}$. Terrific broth supplemented with $1 \%$ YNB gave the highest yield (Table 6; Fig. 4). Under these conditions, plasmid DNA could be recovered from $E$. coli in amounts similar to those obtained from the original $P$. haemolytica isolates or $P$. haemolytica transconjugants. A similar but slightly less pronounced amplification was achieved when $\mathrm{Cm}$ was replaced by Tc (data not shown).

Higher yields of plasmids pPH2, pPH33 and pPH821, but less of plasmid pPH843, were achieved from $E$. coli JM83 transformants than from their DH1 counterparts following identical amplification procedures (data not shown). $H$. influenzae plasmid pRM3022 $(4.4 \mathrm{~kb})$ was amplified to a similar extent to that of $P$. haemolytica plasmid pPH843 in E. coli strain JM83 (Fig. 5).

\section{Restriction enzyme analysis of plasmid DNA}

Of 42 restriction enzymes tested, 12 were found to cut $P$. haemolytica plasmids pPH2, pPH33, pPH821 and pPH843 giving fragments of identical size. These enzymes were $A l u I$ (10 fragments), Sau 3 AI, TaqI, CfoI (5 fragments each), DraI, ThaI (3 fragments each), Hinf I, ScaI (2 fragments each), PstI, ApaLI, AvaI and $B s p 1286$ I (1 fragment each). Representative restriction digests of plasmid pPH843 are shown in Fig. 6A; the unique sites for the latter four enzymes were confirmed by double digestion (lanes 7-9). The prototype ROB-1 plasmid .pRM3022 produced identical restriction patterns to those of pPH843 with all the enzymes except AluI, Sau3AI and DraI. With these three enzymes slight differences were found (Fig. 6B) whereby pRM3022 had two extra $A l u \mathrm{I}$ sites and an additional Sau3AI and DraI site. 


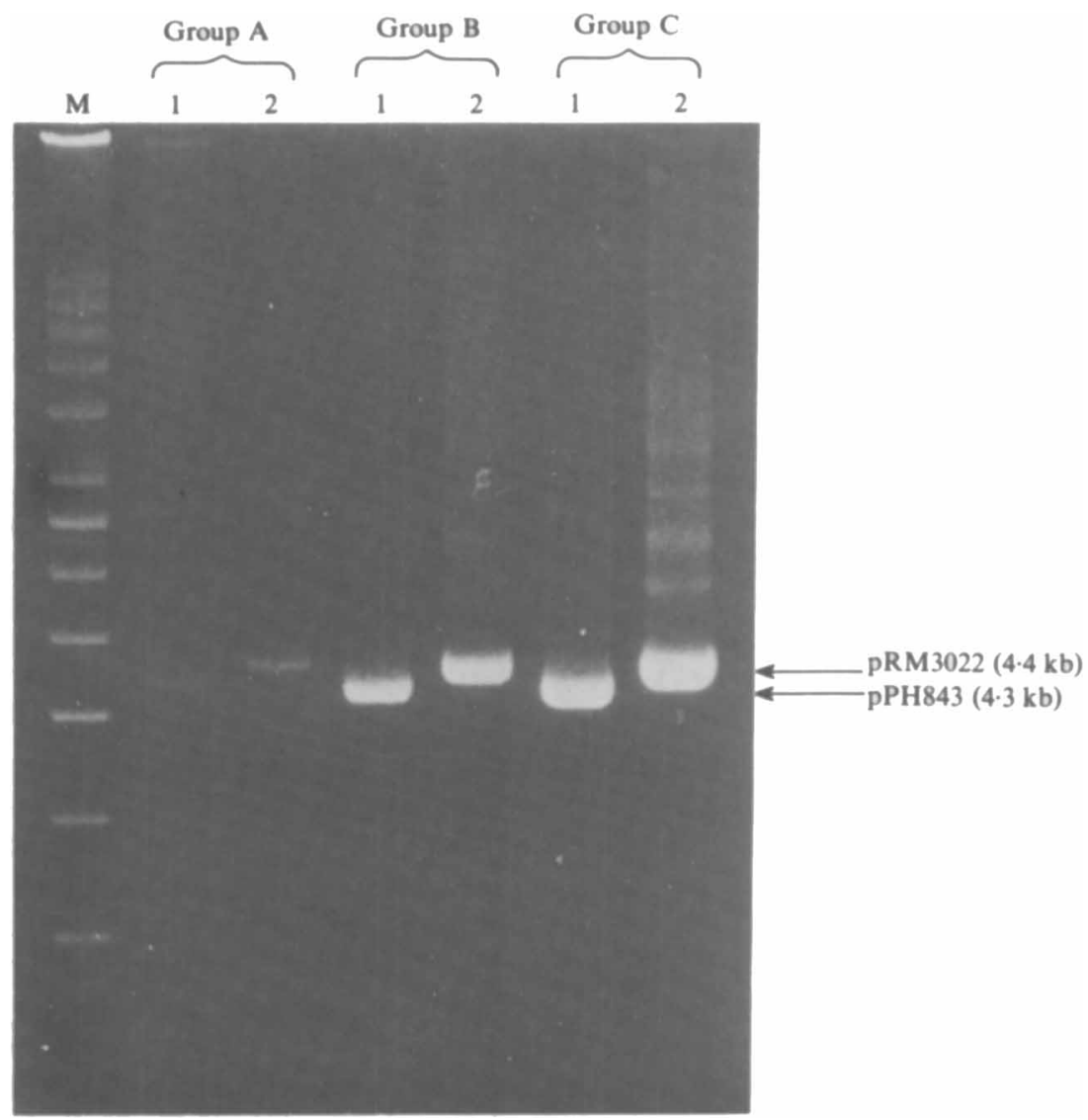

Fig. 5. Agarose gel $(0 \cdot 8 \%)$ showing the yields of $P$. haemolytica $\mathrm{Ap}^{\mathrm{R}}$ plasmid pPH843 (4.3 kb) (lane 1) and $H$. influenzae ROB-type $\beta$-lactamase plasmid pRM3022 (4.4 kb) (lane 2) from $E$. coli JM83 transformants after amplification procedures. The $E$. coli transformants were grown in Terrific broth alone (group A), or Terrific broth $+\mathrm{Cm}$ (group B) or Terrific broth $+1 \%$ YNB $+\mathrm{Cm}$ (group C). M, supercoiled DNA ladder. The upper bands (lane 2; group C) probably represent a 'step ladder' of ccc molecules with different numbers of supercoil turns (Kieser, 1984).

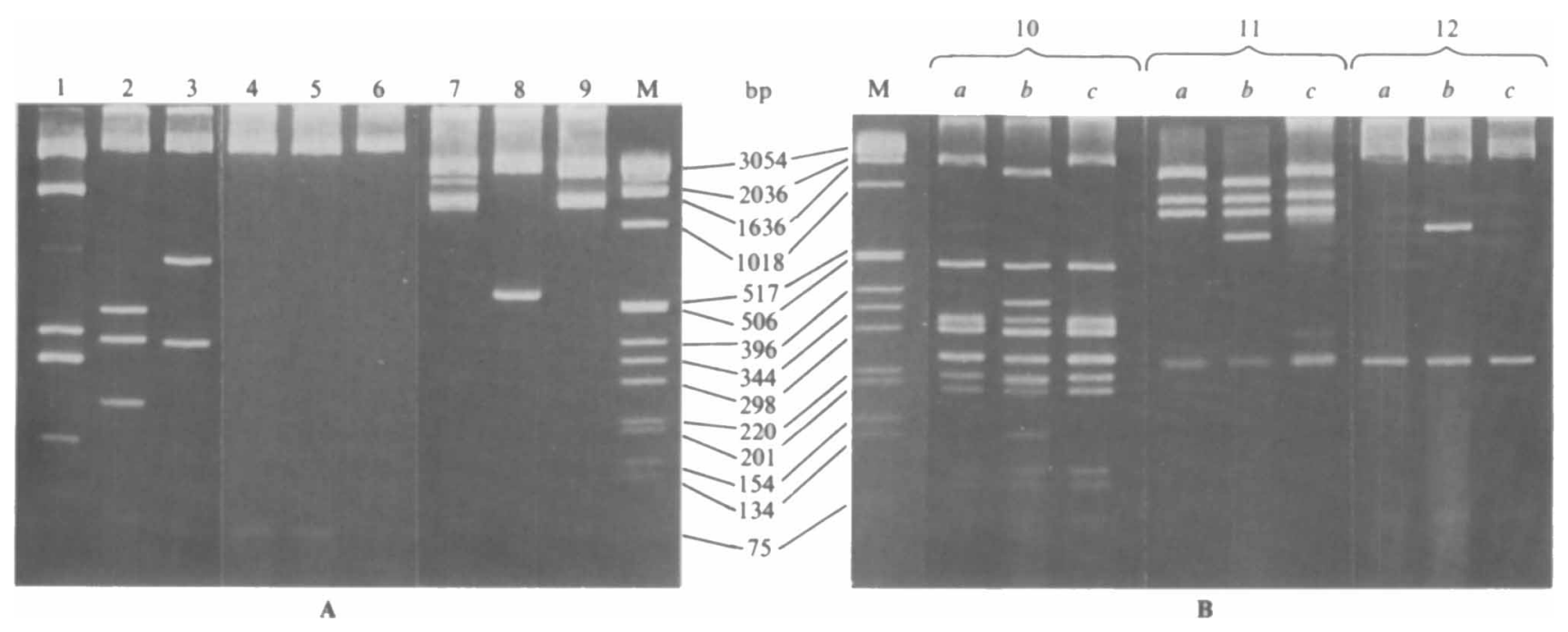

Fig. 6. Restriction enzyme digestion patterns of ROB-1 $\beta$-lactamase-producing plasmids of $P$. haemolytica and $H$. influenzae origin. A: Restriction fragment(s) of plasmid pPH843 generated by the enzymes TaqI (lane 1), CfoI (lane 2), ThaI (lane 3), Hinf I (lane 4), ScaI (lane 5), PstI or ApaLI or AvaI or Bsp1286I (lane 6), ApaLI + PstI (lane 7), AvaI + PstI (lane 8) and Bsp1286I + PstI (lane 9). B: restriction fragments of plasmids pPH33 (lane $a$ ), pRM3022 (lane $b$ ) and pPH843 (lane $c$ ) generated by enzymes $A$ luI (group 10), Sau3AI (group 11) and Dral (group 12). Lane M: 1 kb DNA ladder as molecular size standard. The faint higher molecular mass bands in lanes 1 , $7,10 a$ and $11 c$ are presumed to be partially digested products. 

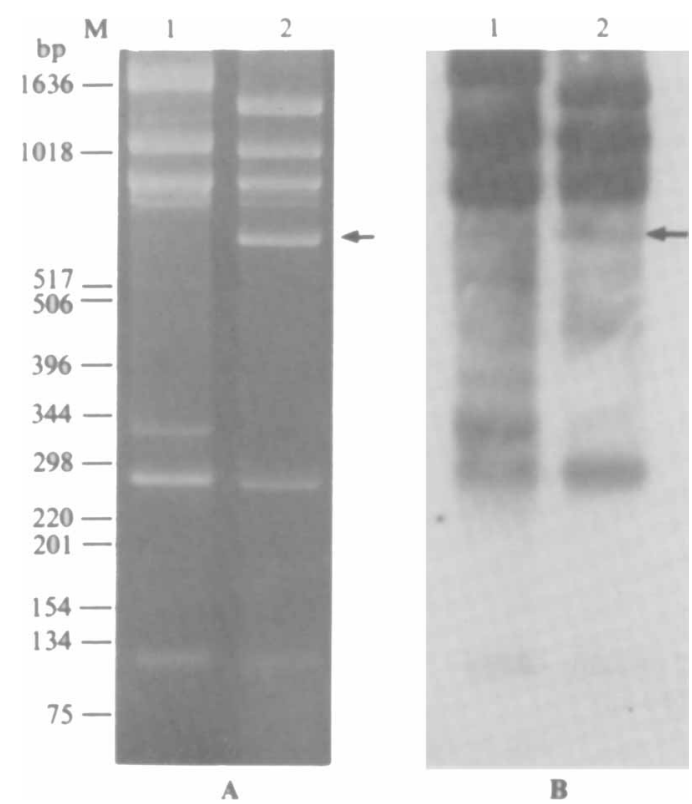

Fig. 7. Homology between the ROB-1-producing plasmids. A : ethidium-bromide-stained agarose gel $(1.8 \%)$ showing Sau3AIdigested fragments of plasmids pPH843 (lane 1) and pRM3022 (lane 2). B: autoradiograph of a Southern blot of the gel shown in panel A probed with Sau3AI-digested pPH843. Arrow (panel B, lane 2) shows a band exhibiting only faint hybridization, equivalent to $\sim 600 \mathrm{bp}$ fragment of pRM3022 (arrow, panel A, lane 2). M, 1 kb DNA ladder as molecular size standard.

\section{Plasmid DNA hybridization}

Hybridization experiments were carried out to assess the degree of homology between the ROB-1 plasmid from $P$. haemolytica (pPH843) and that from $H$. influenzae (pRM3022). All fragments of pRM3022 obtained by Sau3AI digestion hybridized to Sau3AI-digested ${ }^{32}$ P-labelled pPH843, except one fragment (Fig. 7A, lane 2 , arrowed), which showed only weak hybridization (Fig. 7B, lane 2, arrowed). This indicated a high degree of homology between the two ROB-1 plasmids, but suggested that a part of the DNA sequence from the Haemophilus plasmid was not present in the Pasteurella plasmid.

\section{Discussion}

Plasmid DNA was detected in four serotype A1 strains, three A2 strains and one untypable strain of $P$. haemolytica. The plasmid-bearing isolates of the same serotype showed similar plasmid profiles which clearly differed from the profiles exhibited by the other serotypes. This was noted previously by Boyce $\&$ Morter
(1986). Serotype Al is predominant in bovine pasteurellosis and accounts for over $80 \%$ of $P$. haemolytica isolates (Frank, 1989). In our study, plasmid-mediated Ap resistance was found only in Al strains of bovine origin obtained from different sources. This may well be due to selection pressure created by routine antibiotic treatment of cattle. All of these strains were isolated from pneumonic or in-contact calves (Table 2), but the significance of this is difficult to assess without further examination of a larger number of isolates. Small, nonconjugative plasmids associated with resistance to $\beta$-lactam antibiotics, particularly penicillins, have also been isolated from $P$. haemolytica Al strains in the USA (Chang et al., 1987), France (Livrelli et al., 1988) and Germany (Schwarz et al., 1989). In the UK, multiple resistance to antibiotics, including $\mathrm{Ap}$ and $\mathrm{Pe}$, has been reported (Wray \& Morrison, 1983; Allan et al., 1985; Shoo, 1989), but a detailed analysis of transfer of an $A^{R}{ }^{R}$ plasmid between $E$. coli and $P$. haemolytica has been described only for one strain (Craig et al., 1989). This plasmid, $\mathrm{pPH} 33$, was one of the four $\mathrm{Ap}^{\mathrm{R}}$ plasmids of similar size $(4.3 \mathrm{~kb})$ examined here. Plasmids $\mathrm{pPH} 2$, pPH33 and pPH821 were essentially indistinguishable with respect to their transfer efficiencies, amplification properties and MICs with various $\beta$-lactam antibiotics. Plasmid pPH843 had a similar size $(4.3 \mathrm{~kb})$ to the other three, but had a lower copy number in the wild-type $P$. haemolytica strain S/C 84/3 (Fig. 1, lane 4) which was reflected in a $\beta$-lactamase-negative phenotype on test strips and low MIC values. Plasmid DNA preparations from strain $\mathrm{S} / \mathrm{C} 84 / 3$ consistently yielded a low number of $\mathrm{Ap}^{\mathrm{R}}$ transformants. In contrast, an E. coli $\mathrm{DH} 1$ transformant containing pPH843 was strongly $\beta$-lactamase positive on a test strip, showed a strikingly high increase in MIC values for $\beta$-lactams and yielded the highest transfer frequency by conjugation. It is possible that the co-existing plasmids in $P$. haemolytica strain $\mathrm{S} / \mathrm{C}$ $84 / 3$ suppress the copy number of pPH843. This was substantiated by the observation that when the plasmid was transferred from the original host strain to another $P$. haemolytica strain, A2S, the $\beta$-lactamase phenotype was positive and the MIC values were comparable to those of the other $\mathrm{Ap}^{\mathrm{R}}$ plasmids in $\boldsymbol{P}$. haemolytica. It is interesting in this respect to note that each of the plasmids expressed $\mathrm{Ap}^{\mathrm{R}}$ in the $\boldsymbol{P}$. haemolytica $\mathrm{A} 2$ strain, yet no natural antibiotic resistance associated with plasmid DNA was found in three plasmid-bearing A2 isolates (Table 2). This is in keeping with the observations that each serotype appears to maintain a distinct plasmid profile and that transfer of plasmids between serotypes may not readily occur in nature.

Plasmids pPH2, pPH33 and pPH821 were very unstable in $E$. coli and were rapidly lost after passage in the absence of antibiotic selection. Plasmid pPH843, on 
the other hand, was stable even after 10 passages in the absence of selection (data not shown). The lower specific activities of $\beta$-lactamases specified by the former three plasmids (Table 5) may be due to their instability in E. coli. Interestingly, pPH843 was detectable in plasmid DNA preparations from $E$. coli JC3272 transconjugants (Fig. 2), but not from E. coli DH1 or JM83 transformants, suggesting host strain differences in terms of plasmid content.

The MIC values for all the plasmids in $E$. coli were noticeably increased over the values obtained with $P$. haemolytica hosts (Table 4). The differences are comparable to or higher in most cases than those reported by Livrelli et al. (1988) for a ROB-type Ap ${ }^{R}$ plasmid of similar size isolated from bovine Pasteurella strains. Differences in MICs between the plasmid-free $P$. haemolytica and $E$. coli strains (Table 4) could be due to differences in outer membrane permeability or the native chromosomally encoded $\beta$-lactamase present in $E$. coli K12 (Matthew et al., 1975). Zimmerman \& Hirsh (1980) described a bovine isolate of $P$. haemolytica with a plasmid-associated $\beta$-lactamase which had high activity against cephaloridine in cell extracts. Our data indicate little resistance to the cephalosporin class of $\beta$-lactams by the original and transconjugant $P$. haemolytica isolates, but higher resistance of $E$. coli transformants containing the $A \mathrm{p}^{\mathrm{R}}$ plasmids, particularly $\mathrm{pPH} 843$. The sensitivity and substrate profiles of the ROB- and TEM-type $\beta$ lactamases have been reported to be similar (Guttmann et al., 1988) and this was confirmed in the present study (Tables 4 and 5). The ROB-1 $\beta$-lactamase has been differentiated from the TEM-1 enzyme by its higher $\mathrm{pI}$ and its ability to hydrolyse ampicillin more rapidly and cephaloridine more slowly (Rubin et al., 1981). Our results (Table 5; Fig. 3) confirmed that all four $\mathrm{Ap}^{\mathrm{R}}$ plasmids encode enzymes of the ROB-1 type. The ROB1-encoding plasmid was first identified in $H$. influenzae of human origin (Rubin et al., 1981) and later in Actinobacillus pleuropneumoniae of animal origin (Medeiros et al., 1986).

A $P$. haemolytica isolate harbouring the ROB-1 plasmid was first reported in France (Livrelli et al., 1988). Our findings confirm the widespread nature of ROB- $1 \beta$ lactamase-producing strains among the isolates of $P$. haemolytica A1 serotype. The fact that the ROB-1 plasmids examined here could be easily mobilized by conjugation (from E. coli) may explain the spread of such plasmids, although it does not explain the apparent absence of these plasmids in serotypes other than A1.

Previous investigators have reported that the recovery of $P$. haemolytica $\mathrm{Ap}^{\mathrm{R}}$ plasmids from $E$. coli transformants was either poor (Livrelli et al., 1988; Craig et al., 1989) or non-existent (Zimmerman \& Hirsh, 1980). Similar results were obtained in this study, but we found that the $P$. haemolytica plasmids in $E$. coli could be amplified by manipulation of the growth conditions. The amplification of ColE1-type plasmids in $E$. coli by inhibition of protein synthesis with $\mathrm{Cm}$ (Clewell, 1972) or amino acid starvation (Schroeter et al., 1988) is well established. More recently, amplification of plasmid pBR322 in E. coli was reported without blocking protein synthesis by using amino acid and $\mathrm{Fe}^{3+}$ supplements (Angelov \& Ivanov, 1989). In all these cases, the extent of amplification depended on the growth medium used. In our work, LB broth and Terrific broth proved most useful, probably due to the absence in these media of glucose which influences the formation of DNA-protein relaxation complexes during plasmid DNA replication in E. coli (Clewell \& Helinski, 1972). We observed highest amplification in Terrific broth, which was specifically formulated for plasmid and cosmid production (Tartof \& Hobbs, 1987). The reason for obtaining the best yield of plasmids from YNB-supplemented Terrific broth is not clear, but might be due to the presence of multivitamins, amino acids and metal ions, including $\mathrm{Fe}^{3+}$. However, the further addition of amino acids and/or $\mathrm{Fe}^{3+}$ to YNB-supplemented Terrific broth reduced the amplification rate for plasmids (data not shown), which contrasts with the findings of Angelov \& Ivanov (1989).

Restriction enzyme analysis and hybridization experiments demonstrated that the prototype ROB- $1 \beta$ lactamase-encoding plasmid pRM3022 from $H$. influenzae and those isolated from the $P$. haemolytica strains shared multiple fragments, but that they were not identical. Plasmid pRM3022 was slightly larger (4.4 kb) than the $P$. haemolytica plasmids $(4 \cdot 3 \mathrm{~kb})$ and this was reflected in the presence of extra $A l u \mathrm{I}$, Sau $3 \mathrm{AI}$ and $\mathrm{DraI}$ sites (Fig. 6B) and only weak hybridization of one $\sim 600$ bp Sau3AI fragment to pPH843 (Fig. 7, arrowed). As the hybridization was performed under high stringency conditions, this suggests that a major portion of the DNA sequence of this fragment is not present in pPH843. However, the data suggest a close relationship between the ROB-1-producing plasmids from the two different species and that one plasmid might have evolved from the other either by deletion or by recombination with pre-existing cryptic plasmids in the respective strains. Livrelli et al. (1991) have also recently reported homology between ROB-1 $\beta$-lactamase-encoding plasmids from Pasteurella isolates in France and Haemophilus strains. Since the restriction profiles of the four $P$. haemolytica $\mathrm{Ap}^{\mathrm{R}}$ plasmids examined in this study were identical, they offered no explanation for the greater stability and higher amplification in $E$. coli of pPH843 compared to the other three plasmids.

The authors are grateful to Drs H. A. Gibbs of Glasgow University Veterinary School, Glasgow, W. Donachie of the Moredun Research 
Institute, Edinburgh, UK and C. Wray of the Central Veterinary Laboratory, Surrey, UK for their generous donations of $P$. haemolytica strains and Dr D. J. Platt, University Department of Bacteriology, Glasgow Royal Infirmary, UK and Professor E. R. Moxon, Institute of Molecular Medicine, Oxford University, UK for providing $\beta$-lactamase plasmid-containing $E$. coli strains. A. K. Azad was the recipient of a Commonwealth Scholarship.

\section{References}

Achtman, M., Willets, N. \& Clark, A. J. (1971). Beginning a genetic analysis of conjugational transfer determined by the $F$ factor in Escherichia coli by isolation and characterization of transfer-deficient mutants. Journal of Bacteriology 106, 529-538.

Allan, E. M., Wiseman, A., Gibis, H. A. \& Selman, I. E. (1985). Pasteurella species isolated from the bovine respiratory tract and their antimicrobial sensitivity pattern. Veterinary Record 117 , $629-631$.

ANGelov, I. \& IVANOV, I. (1989). Amplification of bacterial plasmids without blocking protein biosynthesis. Plasmid 22, 160-162.

BARRY, A. L. \& THORNSBERRY, C. (1980). Susceptibility tests: diffusion test procedures. In Manual of Clinical Microbiology, pp. 463-474. Edited by E. H. Lennette, A. Balows, W. J. Hausler \& J. P. Truant. Washington, DC: American Society for Microbiology.

BOYCE, J. R. \& MORTER, R. L. (1986). Plasmid profile analysis of bovine isolates of Pasteurella haemolytica. American Journal of Veterinary Research 47, 1205-1207.

BRADFORD, M. M. (1976). A rapid and sensitive method for the quantitation of microgram quantities of protein using the principle of protein-dye binding. Analytical Biochemistry 72, 248-254.

Chang, Y. F., Renshaw, H. W. \& Young, R. (1987). Pneumonic pasteurellosis: examination of typable and untypable Pasteurella haemolytica strains for leukotoxin production, plasmid content, and antimicrobial susceptibility. American Journal of Veterinary Research 48, 378-384.

Clewell, D. B. (1972). Nature of ColE1 plasmid replication in Escherichia coli in the presence of chloramphenicol. Journal of Bacteriology 110, 667-676.

Clewell, D. B. \& Helinski, D. R. (1972). Effect of growth conditions on the formation of the relaxation complex of supercoiled ColEl deoxyribonucleic acid and protein in Escherichia coli. Journal of Bacteriology 110, 1135-1146.

Craig, F. F., Coote, J. G., Parton, R., Freer, J. H. \& Gilmour, N. J. L. (1989). A plasmid which can be transferred between Escherichia coli and Pasteurella haemolytica by electroporation and conjugation. Journal of General Microbiology 135, 2885-2890.

Datta, N., Hedges, R. W., Shaw, E. J., Sykes, R. B. \& Richmond, M. H. (1971). Properties of $\mathbf{R}$ factor from Pseudomonas aeruginosa. Journal of Bacteriology 108, 1244-1249.

DONACHIE, W. (1988). Pasteurella haemolytica as a respiratory tract pathogen of sheep. In Bacterial Infections of Respiratory and Gastrointestinal Mucosae. Special Publications of the Society for General Microbiology vol. 27, pp. 57-66. Edited by W. Donachie, E. Griffith \& J. Stephen. Oxford: IRL Press.

FeInBerG, A. P. \& Vogelstein, B. (1984). A technique for radiolabeling DNA restriction endonuclease fragments to high specific activity. Analytical Biochemistry 137, 266-267.

FiguRSKI, D. H. \& HELINSKI, D. R. (1979). Replication of an origincontaining derivative of plasmid RK2 dependent on a plasmid function provided in trans. Proceedings of the National Academy of Sciences of the United States of America 76, 1648-1652.

Frank, G. H. (1989). Pasteurellosis of cattle. In Pasteurella and Pasteurellosis, pp. 197-222. Edited by C. Adlam \& J. M. Rutter. London: Academic Press.

Guttmann, L., Williamson, R., Collatz, E. \& Acar, J. F. (1988). Mechanisms of beta-lactam resistance in Haemophilus influenzae. European Journal of Clinical Microbiology and Infectious Disease 7, 610-615.
Haghour, R., Hellmann, E. \& Schmidt, J. (1987). Plasmids and resistance to 9 chemotherapeutic agents of Pasteurella multocida and Pasteurella haemolytica. Journal of Veterinary Medicine B34, 509-518.

KIESER, T. (1984). Factors affecting the isolation of CCC DNA from Streptomyces lividans and Escherichia coli. Plasmid 12, 19-36.

Kontomichalou, P., Mitani, M. \& Clowes, R. C. (1970). Circular $\mathbf{R}$-factor molecules controlling penicillinase synthesis, replicating in Escherichia coli under either relaxed or stringent control. Journal of Bacteriology 104, 34-44.

Livrelli, V. O., Darfeuille-Richaud, A., Rich, C. D., JolY, B. H. \& MarTel, J.-L. (1988). Genetic determinant of the ROB-1 $\beta$ lactamase in bovine and porcine Pasteurella strains. Antimicrobial Agents and Chemotherapy 32, 1282-1284.

Livrelli, V., Peduzzi, J. \& Joly, B. (1991). Sequence and molecular characterization of the ROB-1 $\beta$-lactamase gene from Pasteurella haemolytica. Antimicrobial Agents and Chemotherapy 35, 242-251.

Matthew, M., Harris, A. M., Marshall, M. J. \& Ross, G. W. (1975). The use of analytical isoelectric focusing for detection and identification of $\beta$-lactamases. Journal of General Microbiology 88, 169-178.

Medeiros, A. A., Cohenford, M. \& Jacoby, G. A. (1985). Five novel plasmid-determined $\beta$-lactamases. Antimicrobial Agents and Chemotherapy 27, 715-719.

Medeiros, A. A., Levesque, R. \& Jacoby, G. A. (1986). An animal source for the ROB-1 $\beta$-lactamase of Haemophilus influenzae type $\mathrm{b}$. Antimicrobial Agents and Chemotherapy 29, 212-215.

MEYNELL, E. \& DATTA, N. (1966). The relation of resistance transfer factors to the F-factor (sex-factor) of Escherichia coli K12. Genetical Research 7, 134-140.

Ross, G. W. \& O'Callaghan, C. H. (1975). $\beta$-Lactamase assays. Methods in Enzymology 43, 69-85.

Rubin, L. G., Medeiros, A. A., Yolken, R. H. \& Moxon, E. R. (1981). Ampicillin treatment failure of apparently $\beta$-lactamasenegative Haemophilus influenzae type $\mathrm{b}$ meningitis due to novel $\beta$-lactamase. Lancet ii, 1008-1010.

SambroOK, J., Fritsch, E. F. \& Maniatis, T. (1989). Molecular Cloning : a Laboratory Manual, 2nd edn. Cold Spring Harbor, NY: Cold Spring Harbor Laboratory.

SCHROETER, A., RIETHDORF, S. \& HECKER, M. (1988). Amplification of different ColEl plasmids in Escherichia coli relA strain. Journal of Basic Microbiology 28, 553-555.

Schwarz, St, SpIes, U., Reitz, B., Seyfert, H.-M., Lammler, Ch. \& BLOBEL, H. (1989). Detection and interspecies-transformation of a $\beta$ lactamase-encoding plasmid from Pasteurella haemolytica. Zentralblatt für Bakteriologie und Hygiene A270, 462-469.

SHoo, M. K. (1989). Comparing different isolates of Pasteurella haemolytica from beef calves using their in vitro antimicrobial sensitivity patterns. Veterinary Microbiology 20, 73-78.

TARTOF, K. D. \& HoBBS, C. A. (1987). Improved media for growing plasmid and cosmid clones. Bethesda Research Laboratory Focus $\mathbf{9}$, 12.

Vieira, J. \& Messing, J. (1982). The pUC plasmids, an M13mp7derived system for insertion mutagenesis and sequencing with synthetic universal primers. Gene 19, 259-268.

W ASHINGTON, J. A. \& SUTtER, V. L. (1980). Dilution susceptibility test: agar and macro-broth dilution procedures. In Manual of Clinical Microbiology, pp. 453-456. Edited by E. H. Lennette, A. Balows, W. J. Hausler \& J. P. Truant. Washington, DC: American Society for Microbiology.

WRAY, C. \& MorRISON, J. R. A. (1983). Antibiotic resistant Pasteurella haemolytica. Veterinary Record 113, 143.

YATES, W. D. G. (1982). A review of infectious bovine rhinotracheitis, shipping fever pneumonia and viral-bacterial synergism in respiratory disease of cattle. Canadian Journal of Comparative Medicine 46, $225-263$.

Zasloff, M., Ginder, G. D. \& Felsenfeld, G. (1978). A new method for the purification and identification of covalently closed circular DNA molecules. Nucleic Acids Research 5, 1139-1151.

Zimmerman, M. L. \& Hirsh, D. C. (1980). Demonstration of an R plasmid in a strain of Pasteurella haemolytica isolated from feedlot cattle. American Journal of Veterinary Research 41, 166-169. 